\title{
THE CYCLICAL REPRESENTATION OF THE UK CONFERENCE SECTOR'S LIFE CYCLE: THE USE OF REFURBISHMENTS AS REJUVENATION TRIGGERS
}

\author{
JULIE WHITFIELD \\ School of Services Management, Dorset House, Talbot Campus, Fern Barrow, Poole, Dorset, UK
}

\begin{abstract}
Butler's tourism area life cycle (TALC) model is one of the most influential and frequently quoted tourism-related life cycle frameworks. Extensively applied and critiqued, it remains a cornerstone in tourism research. The model classifies the hypothetical temporal development of a destination into a series of stages, these being exploration, involvement, development, consolidation, stagnation and decline, and/or rejuvenation, which when aggregated are represented diagrammatically as a S-shaped curve. This article presents a theoretical extension of the TALC model, based on the decade in which UK conference venues initiated their conference product life cycle, and the use of refurbishments as state changing triggers to rejuvenate the conference product life cycle. This theoretical extension is applied to the four conference venue classifications that together constitute the UK conference sector, namely purpose-built venues, hotels, educational establishments, and visitor attractions. Each of these venue types initiated its life cycle at different times, with individual venues progressing through their life cycle and either stagnating or rejuvenating through the use of refurbishments at differing times throughout the last five decades. Based on these findings, a linear model can be applied to the development of the UK conference sector. However, undertaking refurbishments, and thus the rejuvenation of the conference venues' life cycle, are occurring at differing times, and therefore this article forwards the view that today a cyclical model is more appropriate to the UK conference sector.
\end{abstract}

Key words: UK conference sector; Cyclical representation; Refurbishment; Rejuvenation; Butler tourism area life cycle (TALC)

Introduction

The modern UK conference sector is both dynamic and evolving. Its origins are found at the commencement of the postwar era, evolving over subsequent decades. Through this evolution, the conference sector has become one of the fastest growing and highest yielding sectors within the overall UK tourism industry (Business Tourism Partnership, 2003). It is also an important genera-

Address correspondence to Dr. Julie Whitfield, Events Management Lecturer, School of Services Management, Dorset House, Talbot Campus, Fern Barrow, Poole, Dorset, BH12 5BB, UK. Tel: +44 (0) 1202 965158; Fax: +44 (0) 1202 515707; E-mail: jwhitfield@ bournemouth.ac.uk 
tor of tourism expenditure, investment, foreign exchange earnings, and employment (Abbey \& Link, 1994; Dwyer \& Forsyth, 1996; Oppermann, 1996). Four mutually exclusive venue classifications can be seen within the UK conference sector, that of purpose-built venues, hotels, educational establishments, and visitor attractions, all offering conference facilities (Whitfield, 2005). Together these four venue classifications have become a major competitor in the global conference market place.

Each conference venue has a market to which they are promoted and sold. Purpose-built venues differentiate themselves from the other three venue classifications by offering large delegate capacities. For this reason they are particularly attractive to conferences, meetings, and events held by associations. An association being defined as "An organization of persons having a common interest. The common interest can relate to a variety of interests such as vocational, recreational or political" (Hoyle, Dorf, \& Jones, 1989, cited by Falk \& Pizam, 1991, p. 115). Association members meet for several purposes such as the giving and gathering of information, planning activities of the association, or electing officers as leaders (Hoyle et al., 1989). Association meetings are some of the largest held throughout the world (Crouch \& Weber, 2002). Research by the British Tourism Association (1998) showed that in 1997, more than a third of association meeting were attended by over 500 delegates, with $60 \%$ of association conferences lasting for 3 days or more. Due to these characteristics, quite often an annual association meeting can create demand for delegate accommodation across the entire destination.

Hotels attract corporate conferences, meetings, and events. The corporate conference sector contains a number of unique characteristics. They tend to have a small number of delegates, generally less than 100 , with the majority being attended by between 26 and 50 delegates (Robinson \& Callan, 2001), and are often short in duration (Lawson, 2000). Research from within the UK identifies that $50 \%$ of corporate conferences were attended by 100 delegates or less and that $40 \%$ lasted for 1 day only. In light of these facts, the majority of corporate meetings have short lead times and are held within hotels facilities as part of an incentive package to their delegates (British Tourist Authority, 1998).

Unlike other conference classifications discussed, visitor attractions with conference facilities have a unique selling point (Leask \& Hood, 2000; Saunders, 2001). "They offer a more creative setting than a standard conference suite... attractions are usually the first choice for a themed event" (Wills, 2002, p. 38) and "are often more flexible than hotels in terms of access times, theming and decorating" (Saunders, 2001, p. 41). They provide so much to do and see, unlike any regular hotel or purpose-built centers (Saunders, 2001).

When visitor attractions are compared with other venues classifications, it can be seen that they offer a completely different product and experience. In general, they provide small meeting room facilities, with catering services available inhouse or contracted in and a limited equipment base offering the basic equipment necessary (e.g., overhead projector and flip charts). The duration of events is shorter than the UK conference average, 1.2 compared to 1.5 , which perhaps also reflects on the lack of accommodation offered by many visitor attractions and the overall trend towards shorter events (British Tourist Authority, 1999). Figures for monthly distribution show that peak months for events were March, April, June, and October (Spiller \& Ladkin, 2001). These are months when many of this venue type are not busy, such as attractions or historic houses, where peak business is July and August. This means the conference business provides opportunities for shoulder month revenue generation, lessening the effects of seasonality (Leask \& Hood, 2000).

The single most significant characteristic of educational establishments, with respect to conferences, is that they are built with "learning spaces," such auditoria, lecture theaters, and classrooms are all suited to conference activity (Davidson \& Cope, 2003). Therefore, markets for conferences held in educational establishments tend to have a strong academic orientation and membership, with scientific and cultural subjects predominant. Educational establishments have the advantage of providing specialized facilities, adequate if not sophisticated accommodation, which, for many delegates, is compensated by low costs and the availability of other sport and social facilities (Rutherford, 1990). 
Such venues "generate much lower revenue per delegate per day than venues such as hotels, but delegate volumes tends to be higher" (Shallcross, 1998, p. B-46). Traditionally, universities have succeeded best in two niche markets: high-attendance, low-budget conferences and the smaller training and management seminar events (Davidson, 1998).

Along with the growth in the four conference sectors has come increased competition. Increased competition has resulted in conference planners and delegates demanding a comprehensive conference package, including a wide range of conference capacities that permits smaller breakout sessions, the provision of modern conference technology, and the provision of overnight accommodation for delegates on-site (Crouch \& Louviere, 2004; Meetings Industry Association, 2000). Additionally, where ineffective practices and processes persist due to inefficient infrastructure, or where contemporary cultural values determines that the venues appearance is unacceptable, refurbishments are likely to take place. In doing so refurbishments are made that together realign the venue with contemporary processes, practices as well as aesthetical values and norms. Refurbishment can therefore be defined as providing "an opportunity to improve the essential performance, specification and aesthetics of a building" (Corus, 2006).

Examples of refurbishment can be seen within each of the four venue classifications across the UK conference sector (Whitfield, 2005). In 2003, the Bournemouth International Conference Bureau (BICB) was established ("Karina Managing," 2003), described as "the towns official one-stop shop offering a full and impartial service to conference, meeting and event planners" (Bournemouth International Conference Bureau, 2007a). The BICB's aim is to attract conferences, meetings and events to Bournemouth through the provision of services including finding a venue and finding overnight accommodation for delegates (Bournemouth International Conference Bureau, 2007a). However, in the knowledge that "Bournemouth has been losing valuable conference trade because the Bournemouth International Centres' facilities were not up to scratch" (Bournemouth Borough Council 2006a) a $£ 22$ million refurbishment program was initi- ated. In October, 2005 the Bournemouth International Centre (BIC) reopened after the completion of this refurbishment program. This program included the complete refurbishment of the principal conference hall, expanding its capacity to 4,200 seated delegates in a theater style. Additionally, a new $1,500-\mathrm{m}^{2}$ conference hall has been created with a capacity of 1,600 seated theater style. The foyers, front of house, catering, and car parking facilities have also been improved (Conference Venues.com, 2008). Overall, the flexibility introduced through the refurbishment program now permits events to occur simultaneously. The venue has been rejuvenated. Subsequent to this rejuvenation, the BIC has hosted a familiarization visit for some of the UK's top conference and event organizers, which included presentations concerning local accommodation as well as a tour of the BICs facilities (Bournemouth International Centre, 2007). Additionally, the BICB become the first UK conference bureau to provide functionality that can search conference and meeting room availability for event organizers via the BICB Internet presence (Conference \& Incentive Travel, 2006); the BICB also issued a Conference, Meetings and Services Directory, which details the area's venues and support services (Bournemouth International Conference Bureau, 2007b). The net effect of providing refurbished facilities alongside promotional activities has resulted in bookings being placed up to 2014 (Bournemouth Borough Council, 2006a, $2006 \mathrm{~b}$ ), turnover has increased by $50 \%$ in the first full year of operation since refurbishment, with turnover being better than the predicted value for 5 years on (Joint Consultative Committee, 2007). In July 2008, the International Association of Congress Centres (IAPC) voted the BIC as one of its finalists in the 2008 AIPC Apex Award for the World's Best Convention Centre (International Association of Congress Centres, 2008).

Experiences of extending the venues life cycle can also be seen within hotel conference venues, which have experienced similar investment in order to attract both new and repeat visitation (Richards \& Richards, 1994). The Macdonald New Blossoms Hotel in Chester has under gone a £3 million refurbishment program in the first quarter of 2007. Refurbishments of the guest rooms, including restoration of the lead windows and provi- 
sion of LCD televisions, has complimented the technical upgrade of conference facilities (Macdonald, 2007). Overall, "the hotel has been revitalised by the work" (Johnson, 2007, cited in Macdonald, 2007).

By the late 1990s educational establishments were characterized by investment in and taking seriously the importance of offering conference facilities. In the UK since the year 2000, more than $£ 200$ million has been invested in new facilities and the rejuvenation of older facilities by British Universities Accommodation Consortium (BUAC) to upgrade lecture rooms, banqueting facilities, and substantial investment in the standard of student accommodation (Pemble, 2002). Pembroke College, Oxford, which was built in 1699, underwent a refurbishment program in 2005. This focused on the provision of en-suite bedrooms, a fully equipped kitchen, and conference room equipped with integrated digital projector, stereo sound system, disabled access, and induction hearing loop (Conference Oxford, 2005).

Visitor attractions, such as museums, historic venues, and sporting stadiums offering conference facilities, have also undertaken refurbishments. An example of this can be seen at Twickenham Stadium. The stadium's South Stand is being developed to provide both on-site accommodation and an additional $5,000 \mathrm{~m}^{2}$ of conference and exhibition space. This will include a purpose-built conference auditorium and a four-star hotel with 156 bedrooms, with six of these being VIP suites overlooking the pitch. The redevelopment was completed in September 2008. Accompanying the new conference facilities is the "Twickenham Experience," whereby conference delegates can undertake a tour of the stadium, the players' tunnel, and museum (Twickenham Experience, 2008).

Through the implementation of these refurbishment programs, venues across the UK conference sector aim to breath life into stagnating conference facilities, renewing their life cycle by appealing to new and repeat visitation. In a similar way, focusing on growth, decline, and possible rejuvenation, the development of destinations has received considerable attention, such as Butler's (1980) TALC model. Butler adopted the basic principles from Vernon (1966), whose product life cycle model suggests that products go through a number of stages that end in decline. Butler considered a destination to be a product and thus it too would pass through a number of stages that ultimately end in decline. In doing so, his model charts the hypothetical temporal development of a destination in terms of a series of stages defined by growth, change, tourist numbers, limits, and infrastructure, while bringing together the supply and demand factors (Butler, 1980, 2000). These stages are termed exploration, involvement, development, consolidation, stagnation, and poststagnation, which takes the form of decline or rejuvenation. The characteristics of each stage are shown in Table 1.

The TALC model can be viewed as a "hybrid" (Baum, 1998) theory, drawing on the theoretical and conceptual development of prior works within the tourism domain (e.g., Christaller, 1963; Doxey, 1975; Plog, 1972; Stansfield, 1978) as well as drawing influence from literature pertaining to nature's life cycle of wild species (Baum, 1998). Plog's (1973) Psychocentric-Allocentric model was of great importance for the development of Butler's model for two reasons. First, the demand side of tourism is dynamic and provides a basis for linking the changes in destinations (supply) with changes in visitors (demand). Secondly, because the model was based on both empirical work and statistical analysis, limited though these may appear over three decades later, this was not common place within tourism research at the time the model was published (Butler, 2000).

However, Butler's model differentiated itself from previous models discussed. It introduced a theoretical exit from the life cycle in order that the destination can rejuvenate itself and commence the life cycle once more. Therefore, during the final stage of the cycle, the destination can either rejuvenate, which will initiate a new life cycle, or continue to decline. Traditionally, the destination passes through these stages following an S-shaped curve, as shown in Figure 1, with time as the $x$ axis and number of tourists as the $y$-axis.

The period of time each destination takes to progress through the various stages of the model differs. Some destinations may take a few hundred years to reach the stagnation stage, whereas others may pass through the stages within a couple of decades (Cooper, Fletcher, Gilbert, \& Wanhill, 1998). The period of time taken to pass through 
Table 1

The Stages of Butler's TALC Model

\begin{tabular}{|c|c|}
\hline Life Cycle Stage & Characterized by \\
\hline Exploration & $\begin{array}{l}\text { Limited and sporadic visitation by a few adventurous people; Attractions that cater for tourists } \\
\text { do not exist }\end{array}$ \\
\hline Involvement & $\begin{array}{l}\text { Regular numbers of visitors and a defined tourist season created; Local community provides } \\
\text { support services for tourism }\end{array}$ \\
\hline Development & $\begin{array}{l}\text { Outside investment attracted and accessibility enhanced; Well-defined tourism market emerges; } \\
\text { Decline in local participation and control }\end{array}$ \\
\hline Consolidation & $\begin{array}{l}\text { Local economy tied to tourism, with major chain and franchises; Visitor level still rise, but rate } \\
\text { slows; Advertising and marketing increases tourism season; Destination characterized by age- } \\
\text { ing infrastructure }\end{array}$ \\
\hline Stagnation & $\begin{array}{l}\text { Surplus capacity exists; Resulting in economic, social, and/or environmental problems; Peak } \\
\text { number of visitations is reached; Artificial attractions supersede natural/cultural attractions; } \\
\text { Destination is now considered unfashionable }\end{array}$ \\
\hline Poststagnation decline & $\begin{array}{l}\text { Tourists are attracted away by newer destinations; Remainder are weekend/day visitors; Area } \\
\text { disengages from tourism; Area becomes a tourist slum or is devoid of tourism altogether }\end{array}$ \\
\hline Poststagnation rejuvenation & $\begin{array}{l}\text { Dramatic change in the resource-based established; Either new artificial attraction is developed } \\
\text { or unexploited natural resource utilized }\end{array}$ \\
\hline
\end{tabular}

Source: Butler (1980) cited in Tooman (1997, p. 217); Moore and Whitehall (2005).

the model is dependent upon factors such as (Cooper et al., 1998):

- The rate of development

- Access

- Government policy

- Market trends

- Competing destinations.

Individually or as a combination, these factors can delay or accelerate progress through the life cycle stages. Development can cease at any stage of the model until factors change or new factors are introduced. Therefore, the length of each stage and the time taken from exploration to stagnation varies between destinations. The direction (in terms of either decline or rejuvenate) that the resort takes is more likely to be determined by the interaction of government and the resort management in a response to stagnation. This is a crucial stage for the resort, whether the resort will reevolve and survive, or perish and decline. Each stage of this model highlights differing capacity

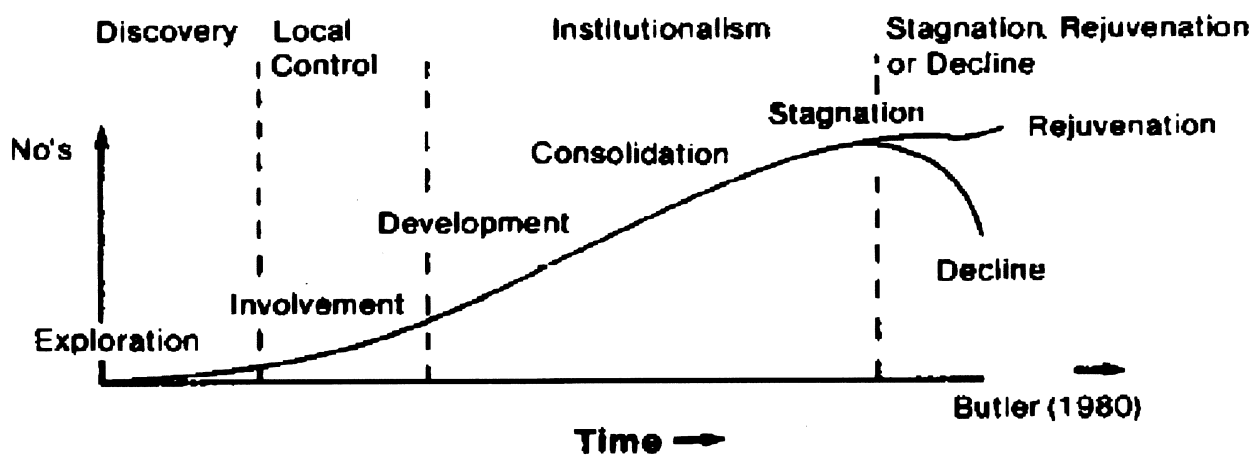

Figure 1. Butler's tourism area life cycle curve. Source: Cooper and Jackson (1989), reprinted with permission from Elsevier. 
thresholds and requires distinct policy responses (Getz, 1994). In addition, during the growth and maturity stages, the management of change is key in order to prevent deterioration or decline. If such decline is experienced, then decisions must be made on whether to rejuvenate the destinations tourism industry and what means, such as incentives, should be used (Getz, 1994). The model is therefore supply generated, focusing on the tourism product, with the advantage of doing so being the embodied challenge for product development, particularly when the stagnation stage is reached (Lundtorp, 2002).

The model is not without its critics. Criticisms specific to this research are twofold. First is that the model lacks geographical scale (Agarwal, 1994; Cooper \& Jackson, 1989; Priestley \& Mundet, 1998; Weaver \& Oppermann, 2002). A destination is comprised of a multitude of differing elements (hotels, attractions, and retail units), each exhibiting their own life cycle. Each element progresses through its own life cycle, with some expanding and others contracting at any given moment in time, thus the unit of analysis is crucial. The second criticism specific to this article is that although Butler accepted the role of entrepreneurs within the involvement stage of the life cycle, their role is not acknowledged in the model's latter stages (Russell \& Faulkner, 2004). In ignoring the role of the entrepreneur in these latter stages Russell and Faulkner (2004) criticize Butler's model for its linear representation of a destinations life cycle, preferring instead to suggest that combining a destinations life cycle with entrepreneurial triggers results in a cyclical representation of the life cycle model, as shown in Figure 2. Therefore, the overall life cycle model is indeed a succession of smaller life cycles as the destination moves forward in response to entrepreneurial activity.

This article accepts the stated criticisms of Butler's TALC model. In response to the first criticism as stated above, the geographical scale employed by this research is at both the conference sector level and at individual venue level. By differentiating between the sector and venue, both are able to pass through a life cycle from inception until stagnation, then decline or rejuvenation. However, venues will pass through their own life cycle at differing rates, some expanding, some contracting, but each one moving between stages at any given moment, and ultimately entering the stagnation stage at differing times. Together, all venues move the UK conference sector through its own overarching life cycle. In response to the second criticism stated above, this article views the implementation of refurbishments as state changing triggers. These state changing triggers may be applied at differing times and with differing intensity. Some refurbishments being small scale others encompassing significant changes to the buildings infrastructure, but the net effect of any refurbishment program will be to initiate a new life cycle. Therefore, new life cycles will be initiated at differing times, resulting in a succession of smaller venue specific life cycles within the overarching life cycle of the UK conference sector.

In light of these responses to the criticisms of Butler's (1980) TALC model, this article forwards the theoretical extension of Butler's TALC model when applied to the UK conference sector and its constituent venues, moving away from a linear representation to a cyclical representation based upon the use of refurbishment programs as state changing triggers. This article continues by identifying empirical data to support this adaptation within the context of the UK conference sector.

\section{UK Research-Methodology}

The empirical data utilized within this article were collected as part of a research program in 2001 , via a postal questionnaire. The addresses for these conference venues were obtained from a number of publications including The Venue: The World-wide Guide to Conference and Incentive Travel Facilities 2000/01 and The Green and Blue Book publication. Secondary sources included UK conference bureaus and local authorities, along with journals, trade magazines, and British Tourism Association publications. A sample of 300 purpose-built venues, 2,000 UK hotels, 148 educational establishments, and 552 visitor attractions all offering conference facilities was utilized.

Data were collected between June and August 2001 inclusive; this period included the sending of reminders. The first letters and questionnaires were sent on June 8, 2001, with a 3-week deadline to be returned. Based on the lessons learned in 


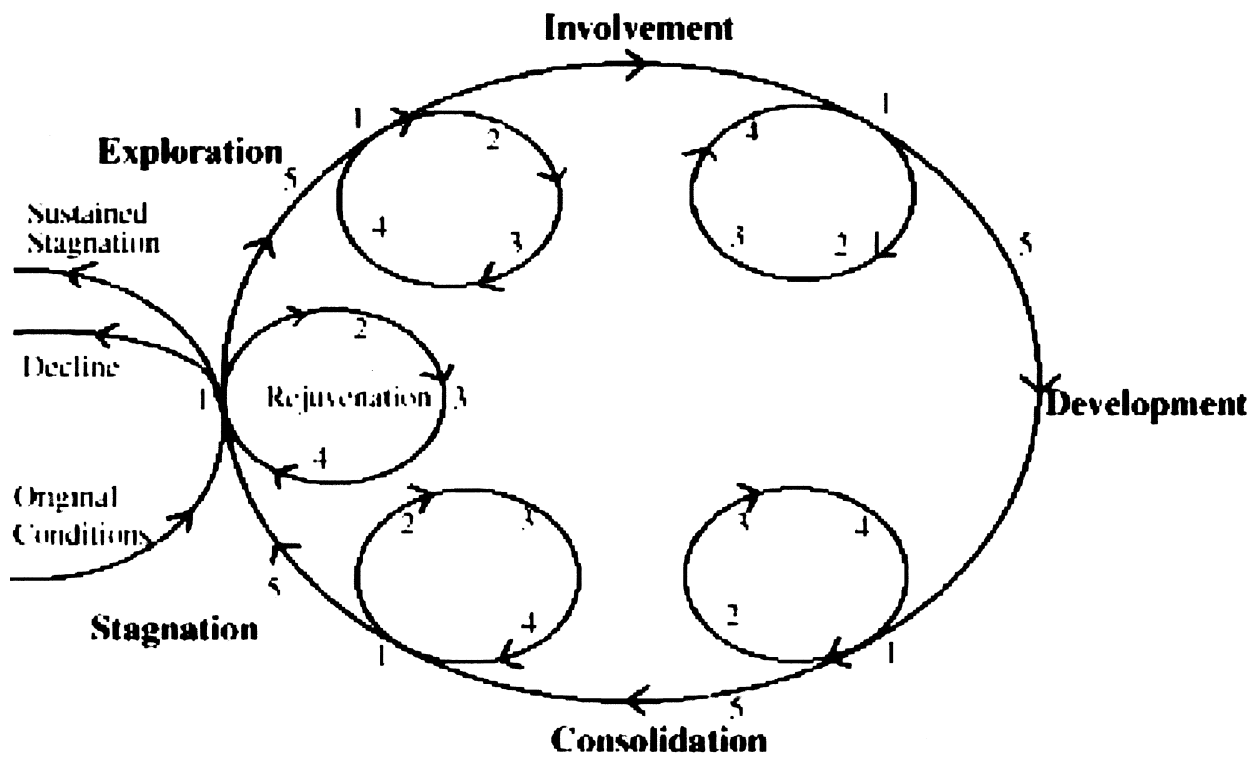

Figure 2. A cyclical representation of Butler's life cycle model with entrepreneurial triggers. Source: Russell and Faulkner (2004, p. 563), reprinted with permission from Elsevier.

the pilot surveys, the addressee was set as "The Conference Manager." After the 3-week deadline passed, $10 \%$ of the initial questionnaires had been returned completed. A cross section of nonrespondents who failed to complete their questionnaire were telephoned, as a reminder. To those 2,700 venues remaining in the survey population and who had not returned their questionnaire, a reminder was sent with an additional copy of the questionnaire and a further stamped addressed envelope. This first reminder was sent on July 2, 2001 with a further 3 -week returning period. A second reminder with a copy of the questionnaire letter was sent to 2,571 in early August, 2001, but no stamped addressed envelope was enclosed due to financial constraints. No attempt was made to determine nonresponse bias. Copies of the questionnaire for all four venue classifications, containing questions relevant to this article, can be obtained from the author (jwhitfield@bournemouth. ac.uk).

The response rates, and breakdown, from each of these venue classifications included 53 (17.6\%) purpose-built venues. These responses were obtained from 22 civic and community halls, 16 purpose-built venues (i.e., built solely for the use of conference, events and meetings), and 15 residential conference centers. A further 286 (14.3\%) hotels responded. This was comprised of 146 chainowned hotels and 140 independent hotels, while only half of respondents provided their geographical location, with 79 hotels stating they considered themselves a rural hotel and 74 as urban. For educational establishments $24(16.2 \%)$ responses were obtained. This comprised 13 universities, five colleges and further educational establishments, while three respondents stated they were purpose-built management training centers (MTCs) located on campus, and three respondents stated they represented MTCs not located on campus. Finally, 75 $(13.6 \%)$ visitor attractions responded. This comprised 18 "sports and leisure" venues, including large sports stadia, golf courses, and horse racing tracks. Castles, country houses, and historic buildings without accommodation closely followed this, accounting for 16 venues. Three separate categories accounted for 11 venues each, that of castles, country houses, and historic buildings with accommodation, as well as museum and gallery along with "other venues." The term "Other venues" includes a diverse range of visitor attractions such as a vineyard, a media center, and an arts 
center. Responses from five theaters and concert halls were received. Finally, two boat and train venues responded, along with one fun park. The overall response rate across the UK conference sector was 438 (15.4\%) venues.

Life Cycle Initiation; The Decade in Which the Conference Facilities Were Added and Opened

In order to establish a baseline with regards to the initiation of the venues life cycles, respondents were asked in which year their venue initially offered conference facilities. The results were categorized by the decade of opening, and are shown in Figure 3.

Figure 3 shows purpose-built conference venues initiated their life cycle in the 1950s, with one (1.9\%) such venue opening during this decade; indeed, this venue opened in 1950. In the 1960s, this rose to five (9.4\%) and during the 1970s seven (13.2\%) such venues had opened. Further growth occurred in the 1980s and 1990s, with 19 (35.9\%) and $21(39.6 \%)$ venues opening, respectively. No respondents stated that their purpose-built venue opened in the years 2000-2001.

Figure 3 also shows that hotels initiated their conference product life cycle in the 1950s, with four venues (1.4\%) stating this was the case. However, these venues opened between 1955 and 1959. The findings identify that the first responding hotels offered conference facilities 5 years after the initial purpose-built conference venue opened. The number of hotels offering conference facilities grew to $17(6 \%)$ in the 1960s, and increased threefold to $51(17.7 \%)$ hotels opening conference facilities in the 1970s. By the 1970s the growth in the number of hotels offering conference facilities exceeded the growth in purposebuilt venues. During the 1980s, as growth continued within the purpose-built venues, so expansion in hotel conference facilities also occurred, with $83(29 \%)$ hotels opening conference facilities during this decade. From the 1980s hotels became a major provider of conference facilities, providing $70 \%$ of the meetings space in the UK (Shone,

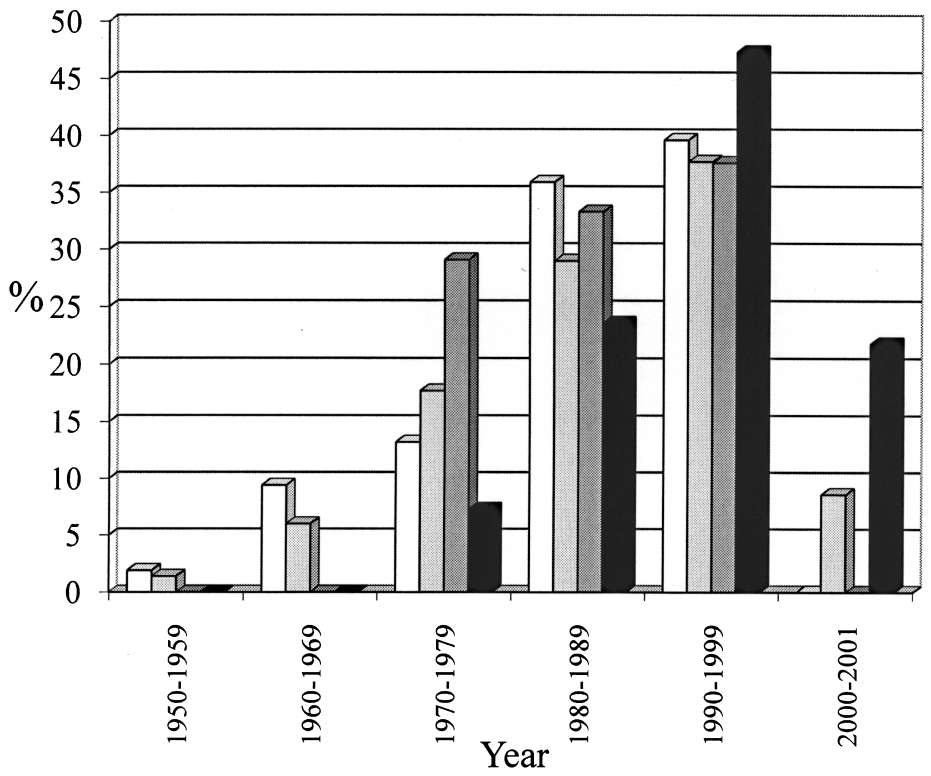

口Purpose Built $\quad$ पHotels aEducational Est $\quad$ QVisitor Attractions

Figure 3. The decade in which conference facilities were added and opened. Purpose-built $(n=53)$, Hotels $(n=283)$, Educational establishments $(n=24)$, Visitor attractions $(n=75)$. 
1998). By the 1990s hotels led the market in terms of supplying conference facilities, accounting for $77 \%$ of all conference venues and $68 \%$ of all delegates' nights (Travel Industry Monitor, 1991). In the 1990s, the greatest level of growth within the responding hotel venues occurred, with 106 (37.3\%) hotels opening conference facilities. Over the postwar decades, hotels have identified the potential of the conference market as a source of revenue, thus adding conference facilities that are now managed as an integral part of the hotel business (Davidson \& Cope, 2003).

Educational establishments first offered conference facilities during the 1970s, with seven (29.1\%) conference facilities opening, as shown in Figure 3. Therefore, purpose-built venues were the first to open, preceding the growth in the hotel market, which in turn was subsequently complimented by the opening of conference facilities within educational establishments. These findings support the work of Paine (1993), who identified that in the early 1970s several educational establishments actively began to market themselves as conference facilities during vacations.

Growth was experienced in the 1980s and 1990s, with eight $(33.3 \%)$ and nine $(37.6 \%)$ educational establishments adding conference facilities, respectively. The 1980s were a decade associated with considerable investment in upgrading facilities, accompanied by an increase in the level of marketing (Davidson \& Cope, 2003). Conferences are now viewed as a significant source of income; as a consequence many venues have developed conference facilities. Many have obtained external funding to build residential facilities and to improve the quality of their conference product (Shone, 1998). No respondent stated their educational establishment opened conference facilities in 2000-2001.

This research identifies that educational establishments initiated their life cycle in the 1970s, approximately one decade after hotels entered the conference sector. It was in this same decade that both purpose-built and hotel conference venues underwent rapid expansion in the provision of such facilities. Similar to hotel development, which identified that conference facilities were a means of diversifying from their core product, educational establishments have identified confer- ence facilities as a similar means of diversification. In doing so, such establishments are able to utilize existing lecture rooms, auditoria, and technical facilities (Whitfield, 2005).

For visitor attractions, the 1970s were also the decade in which they initiated their conference product life cycle, although this venue classification showed little demand for conference facilities with six $(8 \%)$ attractions adding such facilities (Fig. 3). Of these six venues, five opened in the latter part of the decade, between 1975 and 1979. However, through the 1980s and 1990s there was a rapid rise in the number of conference facilities being added to visitor attraction, with $22(29.4 \%)$ and $35(46.6 \%)$ attractions responding. This expansion occurred one decade after educational establishments entered the conference market. As stated, the survey took place in 2001; thus, during 2000 and 2001 the research identified that $12(16 \%)$ attractions within the sample population added conference facilities. This is the largest growth rate in this decade for any of the four venue classifications.

The Rejuvenation of the Conference Product

Life Cycle: The Decade in Which Initial Refurbishments Occurred

Respondents were asked whether or not their conference venue had refurbished since opening; a total of 409 venues responded to this question, with $253(61.9 \%)$ stating that they had done so. In terms of each of the four venues classifications, Table 2 forms the basis for the following discussion.

The most popular decade to refurbish purposebuilt venues was the 1990s. Over $50 \%$ of the responding venues (17 of the 27 venues or $62.9 \%$ ) stated this was the case. However, just over a quarter of responding purpose-built venues refurbished in the 1980 s, with seven $(25.9 \%)$ venues responding. The remaining three $(11.2 \%)$ purposebuilt venues were refurbished in 2000-2001. For hotels, 64 venues supplied a year, with the most popular decade to refurbish also being the 1990s, with $33(51.5 \%)$ hotels doing so. Hotels differ from purpose-built venues in that their second most popular decade to refurbish in was that of 2000-2001, with 26 (40.8\%) doing so. Hotels also 
Table 2

Decade in Which Conference Venue Classifications Refurbished

\begin{tabular}{|c|c|c|c|c|c|c|}
\hline & $1950 \mathrm{~s}$ & $1960 \mathrm{~s}$ & $1970 \mathrm{~s}$ & $1980 \mathrm{~s}$ & $1990 \mathrm{~s}$ & $2000 \mathrm{~s}$ \\
\hline Purpose built & 0 & 0 & 0 & $7(25.9 \%)$ & $17(62.9 \%)$ & $3(11.2 \%)$ \\
\hline Hotels & 0 & 0 & $1(1.5 \%)$ & $4(6.2 \%)$ & $33(51.5 \%)$ & $26(40.8 \%)$ \\
\hline Educational establishments & 0 & 0 & 0 & 0 & $1(50 \%)$ & $1(50 \%)$ \\
\hline Visitor attractions & 0 & 0 & $1(5.6 \%)$ & $1(5.6 \%)$ & $8(44.4 \%)$ & $8(44.4 \%)$ \\
\hline
\end{tabular}

differ in that one $(1.5 \%)$ venue stated it refurbished in the 1970s and the remaining four $(6.2 \%)$ venues refurbished in the 1980 s. Only two educational establishments provided a year in which refurbishments took place, with one stating improvements occurred in the 1990s and the other between 2000 and 2001. For visitor attractions 18 respondents stated a year in which refurbishments took place, both the 1990s and between 2000 and 2001 experienced eight (44.4\%) venues refurbishing. A further one $(5.6 \%)$ visitor attraction refurbished in the 1980s and, like hotels, one (5.6\%) visitor attraction stated they refurbished in the 1970s.

\section{Linear or Cyclical Life Cycle of the UK Conference Sector?}

Similarities can be drawn between the linear conceptual framework of Butler's TALC model and the empirical findings concerning the life cycle of both overall UK conference sector and its constituent conference venues. The progress of the UK conference sector through the life cycle is not determined by the number of tourists, but by the number of venues opening and offering conference facilities.

Utilizing the finding as shown in Figure 1 and the stages of the TALC model, it can be seen from Table 3 that for purpose-built venues, the 1950s can be classified as that of the "exploration" stage as only a small number of venues existed. Purpose-built venues moved into and remained within the "involvement" phase during the 1960s and 1970 s as the number of such venues grew.

Such venues subsequently entered the "development" phase in the 1980 s as rapid growth in such venues occurred. This venue classification is progressing through its life cycle at the slowest rate of any of the four venue classifications, as it commenced its life cycle in the 1950s and is still progressing through it life cycle in 2000-2001. It is predicted to move in to the "consolidation" phase between 2000 and 2009 based upon the predicted number of venues opening in the current decade.

Hotels offering conference facilities entered the "exploration" phase in the 1950s and 1960s. This venue classification subsequently moved to the "involvement" phase in the 1970s as growth in this venue classification increased. In the $1980 \mathrm{~s}$ hotels moved on from the "involvement" phase to enter the "development" phase. Between 2000 and 2009 it is predicted that hotel may move into the "consolidation" stage.

For both educational establishments and visitor attraction, which offer conference facilities, the "exploration" phase was entered during the 1970s. The 1980s was the decade where such venues entered the "involvement" phase. For educational establishments the 1990s is the decade in which this venue classification entered the "development" phase, from which it is predicted to pass into the "consolidation" stage between 2000 and 2009. Finally, visitor attractions remained in the "involvement" stage until passing into the "development" phase during the 1990s as the number of venues in each sector entering the conference sector increases. As the number of visitor attractions is due rise by over $25 \%$ based upon the number of venues opening in 1990-1999, this venue classification is predicted to remain in the "development" stage throughout 2000-2009.

Based upon Table 3, Butler's (1980) linear development curve can indeed be applied across the UK conference sector, with its constituent venue classifications being placed within relevant stages of the TALC model. However, with the application of the finding as shown in Table 2 regarding 
Table 3

Butler's Life Cycle Model Applied to the Conference Sector

\begin{tabular}{|c|c|c|c|c|c|c|}
\hline & $1950-59$ & $1960-69$ & $1970-79$ & $1980-89$ & 1990-99 & $2000-09 *$ \\
\hline Purpose built & $\begin{array}{l}\text { Exploration: } \\
1(1.9 \%)\end{array}$ & $\begin{array}{l}\text { Involvement: } \\
5(9.4 \%)\end{array}$ & $\begin{array}{l}\text { Involvement: } \\
7(13.2 \%)\end{array}$ & $\begin{array}{l}\text { Development: } \\
19(35.9 \%)\end{array}$ & $\begin{array}{l}\text { Development: } \\
21(39.6 \%)\end{array}$ & $\begin{array}{l}\text { Consolidation: } \\
\text { 34* }\end{array}$ \\
\hline Hotels & $\begin{array}{l}\text { Exploration: } \\
4(1.4 \%)\end{array}$ & $\begin{array}{l}\text { Exploration: } \\
17(6 \%)\end{array}$ & $\begin{array}{l}\text { Involvement: } \\
51(17.7 \%)\end{array}$ & $\begin{array}{l}\text { Involvement, De- } \\
\text { velopment: } 83 \\
(29 \%)\end{array}$ & $\begin{array}{l}\text { Development: } \\
106(37.3 \%)\end{array}$ & $\begin{array}{l}\text { Development, } \\
\text { Consolidation } \\
\text { (2000-2001): } 25 \\
(8.6 \%) ; 140 *\end{array}$ \\
\hline $\begin{array}{l}\text { Educational } \\
\text { establishments }\end{array}$ & & & $\begin{array}{l}\text { Exploration: } \\
7(29.1 \%)\end{array}$ & $\begin{array}{l}\text { Involvement: } 8 \\
(33.3 \%)\end{array}$ & $\begin{array}{l}\text { Development: } 9 \\
(37.6 \%)\end{array}$ & $\begin{array}{l}\text { Development, } \\
\text { Consolidation: } \\
10^{*}\end{array}$ \\
\hline Visitor attractions & & & $\begin{array}{l}\text { Exploration: } \\
6(8 \%)\end{array}$ & $\begin{array}{l}\text { Involvement: } 22 \\
(29.4 \%)\end{array}$ & $\begin{array}{l}\text { Involvement, De- } \\
\text { velopment: } 35 \\
(46.6 \%)\end{array}$ & $\begin{array}{l}\text { Development } \\
\text { (2000-2001): } 12 \\
(16 \%), 48^{*}\end{array}$ \\
\hline
\end{tabular}

Source: Whitfield (2005).

*Predicted growth over the decade based upon historical data.

the timings of refurbishment programs it can be seen that venues have initiated new life cycles throughout 1970s, 1980s, 1990s, and the first years of the current decade. Through the initiation of a new life cycle, venues are thus theoretically able to pass once again through the stages of Butler's (1980) life cycle model. Therefore, within the overall life cycle of the UK conference sector its constituent venues are undertaking a number of shorter life cycles, which are being initiated at differing time periods. This is seen in Figure 4, as refurbishments are rejuvenating their life cycle so each of the four venue classifications are undertaking their own cyclical development within the overall life cycle of the UK conference sector, passing through its own life cycle at its own rate.

In summary, Figure 4 shows that as purposebuilt venues are the most mature venue classification; this venue classification is shown as the furthest around the cyclical life cycle. Visitor attractions have the shortest life cycle; this venue classification is shown at the start of the cyclical life cycle. The entire sector is passing through the life cycle stages from Exploration (1 in Fig. 4) through Involvement (2), Development (3), Consolidation (4), and Stagnation (5). As such, each of the venue classifications, and indeed individual venues, are themselves undergoing their own development life cycle (E-Exploration, I-Involvement, $\mathrm{D}$-Development, $\mathrm{C}$-Consolidation, and $\mathrm{S}-$ Stagnation for each of the venue classification in Figure 4. Refurbishment of venue facilities is considered as the trigger in whether or not venue declines/sustained stagnation (Dc/SS in Fig. 4) or rejuvenates $(R)$.

Overall, as the sector passes through the stagnation stage, it can either decline or rejuvenate. Through refurbishing venues the individual venue classifications and collectively the industry passes into the rejuvenation stage. If collectively all individual venue refurbishments are sufficient to maintain a competitive edge for the UK conference sector, then the UK conference sector will pass back into the exploration stage and once more commence the cyclical path of its development life cycle. If venues do not refurbish in order to maintain a competitive advantage, demand is likely to fall and in turn the venue will enter the decline stage. If collectively both individual venues and the entire venue classifications fail to continually meet conference organizer and delegate demands as the sector enters the stagnation stage, where it has the choice to decline or rejuvenate.

\section{Conclusion}

At its outset, this article draws comparisons between Butler's (1980) TALC model and the UK conference sector. Conference venues are considered products, just as Butler considered destina- 
(2) Involvement

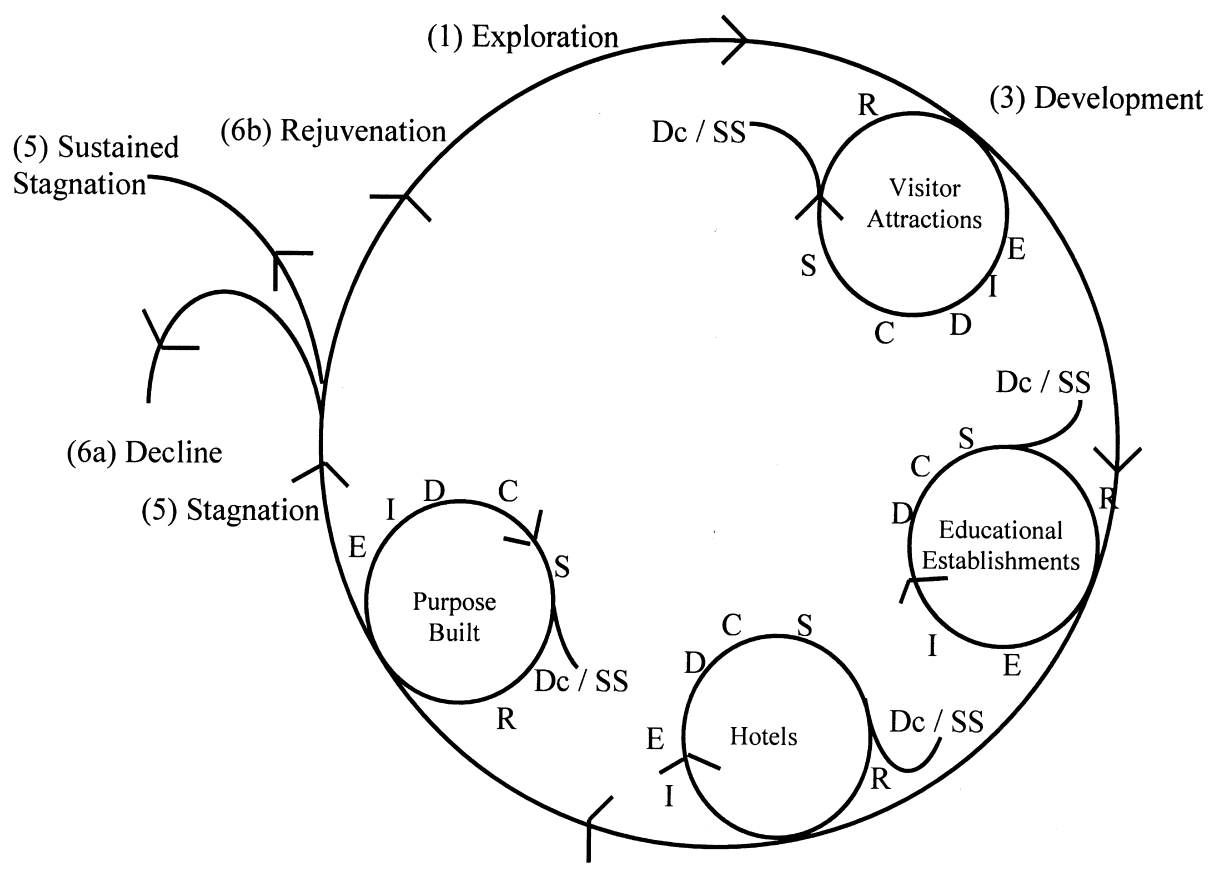

(4) Consolidation

Figure 4. A cyclical representation of the UK conference sector. Adapted from Russell and Faulkner (2004, p. 563). E, exploration; I, involvement; D, development; C, consolidation; S, stagnation; R, rejuvenation; Dc/SS, decline and sustained stagnation.

tions as products. This article also forwarded the theoretical extension of the TALC model based on two criticisms of Butler's model. The first is the lack of geographical scale, and secondly the lack of acceptance of state-changing triggers in the latter stages of the TALC model. In response to these criticisms this article forwards the view that both the UK conference sector and its constituent venues should be differentiated in terms of scale. In response to the second criticism, this article considers conference venue refurbishments as state changing triggers.

The empirical findings of this article have identified that the constituent venue classifications, that together form the UK conference sector, initiated their life cycles at differing times, are currently at differing stages of their life cycles, and are progressing at differing rates through the life cycle stages. Purpose-built venues were the pioneering venue classification followed by hotels, educational establishments, and finally visitor attractions all offering conference facilities.
The article also identifies that the initiation of refurbishment programs, and thus the rejuvenation of venues conference product life cycle, across the four UK conference venue classifications did not occur simultaneously. Hotels and visitor attraction were the first venues to initiate new life cycles through refurbishment programs during the 1970s, although the numbers of venues doing so are smaller. A greater number of venues refurbished in the 1980s, and responding purpose-built venues commenced new life cycles during this decade. The 1990s saw responding educational establishments initiate new life cycle through refurbishments. The 1990s were also a decade in which over half of responding purpose-built venues and hotels commenced refurbishment programs. Between 2000 and 2001 as many visitor attraction have undertaken refurbishments as they did in the entire 1990s.

The UK conference sector is therefore a nonhomogenous product, and although a linear model, such as the TALC model, can be applied to its life 
cycle development, today, due to refurbishments initiating new conference product life cycles at differing times, a cyclical representation of the UK conference sector is more appropriate.

\section{References}

Abbey, J. R., \& Link, C. K. (1994). The convention and meetings sector-its operation and research needsl. In J. R. Brent Ritchie \& C. R. Goeldner (Eds.), Travel, tourism, and hospitality research (2nd ed., pp. 273284). New York: John Wiley and Sons.

Agarwal, S. (1994). The resort cycle revisited-implications for resorts' progress. Tourism, Recreation and Hospitality Management, 5, 194-207.

Baum, T. (1998). Taking the exit route: Extending the tourism area lifecycle model. Current Issues in Tourism, 1, 167-175.

Bournemouth Borough Council. (2006a). BIC boost to leisure and business. Retrieved November 27, 2007, from http://www.bournemouth.gov.uk/News/Major_town_ developments/BIC/default.asp

Bournemouth Borough Council. (2006b). BIC gears up for official opening. Retrieved November 27, 2007, from http://www.bic.co.uk/News/2005/November_2005/offi cialopening.asp

Bournemouth International Centre. (2007). BIC pulls the crowds to Bournemouth. Retrieved February 1, 2009, from http://www.bic.co.uk/aboutus/news2007/arubafam trip.asp

Bournemouth International Conference Bureau. (2007a). Retrieved February 1, 2009 from http://www.bourne mouthconferences.co.uk/index

Bournemouth International Conference Bureau. (2007b). Brand new brochure for BICB. Retrieved February 1, 2009, from http://www.bic.co.uk/aboutus/news2007/bicb brochure2007.asp

British Tourist Authority. (1998). British Conference Market Trend Survey 1997. London: Author.

British Tourist Authority. (1999). British Conference Market Trends Survey 1998. London: Author.

Business Tourism Partnership. (2003). Retrieved from http://www.businesstourismpartnership.com/pubs/mtg \%20mkt.pdf

Butler, R. W. (1980). The concept of a tourist area cycle of evolution implications for management of resources. Canadian Geographer, 24, 5-12.

Butler, R. W. (2000). The resort cycle two decades on. In H. W. Faulkner, G. Moscardo, \& E. Laws (Eds.), Tourism in the twenty-first century: Reflections on experience (pp. 284-299). London: Continuum.

Christaller, W. (1963). Die Zentralen Orte In Sudeutscland (Jena: Gustav Fisher, translated in part by C. W. Baskin C.W. as Central Places in Southern Germany in 1996). Englewood Cliffs, NJ: Prentice Hall.

Conference \& Incentive Travel. (2006). Bournemouth upgrades online venue finding. Retrieved February 1, 2009, from http://www.citmagazine.com/news/search/827268/ Bournemouth-upgrades-online-venue-finding
Conference Oxford. (2005). Conference Oxford news letter, November.

ConferenceVenues.com. (2008). Bigger and better BIC. Retrieved August 27, 2008, from http://www.conference venues.com/conference_venues_uk.asp?venue $=$ Bourne mouth \% 20International \% 20Centre\&conference_loc $=$ Bournemouth

Cooper, C., Fletcher, J., Gilbert, D., Wanhill, S., \& Shepherd, R. (1998). Tourism principles and practice (2nd ed., pp. 116-117). New York: Longman.

Cooper, C. P., \& Jackson, S. (1989). Destination lifecycle: The Isle of Man case study. Annals of Tourism Research, 16, 377-398.

Corus. (2006). Why refurbish. Retrieved October 8, 2006, from http://www.colorcoat-online.com/en/occupation and_use/refurbishment/why_refurbish

Crouch, G. I. \& Louviere, J. L. (2004). The determinants of convention site selection: A logistic choice model from experimental data. Journal of Travel Research, Vol. 43, November 2004, 118-130.

Crouch, G. I., \& Weber, K. (2002). Marketing of convention tourism. In K. Weber \& K. Chon (Eds.), Convention tourism: International research and industry perspectives. New York/London/Oxford: The Haworth Hospitality Press.

Davidson, R. (1998). Travel and tourism in Europe (2nd ed.). Harlow, Essex: Longman.

Davidson, R., \& Cope, B. (2003). Business travel-Conference, incentive travel, exhibitions, corporate hospitality and corporate travel. Harlow, Essex: FT Prentice Hall.

Doxey, G. (1975). When enough's enough: The natives are restless in old Niagara. Heritage Canada 2(2), 26-27.

Dwyer, L., \& Forsyth, P. (1996). MICE tourism to Australia: A framework to assess impacts. In Proceedings of the Australian Tourism and Hospitality Research Conference, Coffs Habours (pp. 313-323). Canberra: Bureau of Tourism Research.

Falk, E. T., \& Pizam, A. (1991). The United States' meetings market. International Journal of Hospitality Management, 10(2), 111-118.

Getz, D. (1994). Destination market for convention and visitor bureaus ( $2 \mathrm{nd}$ ed.). Dubuque, IA: Kendall/Hunt Publishing.

International Association of Congress Centres. (2008). AIPC Apex Award 2008. Retrieved August 27, 2008, from http://www.aipc.org/award_2006.html

Joint Consultative Committee. (2007). Notes of the meeting of the Joint Consultative Committee (GROUP 5) BIC/ Pavilion held on the 25th October. Retrieved February 1, 2009, from http://www.bournemouth.gov.uk/Library/ Committee_Meetings/PERSJCC/Reports/31_January_ 2008/Report\% 20H\% 20JCC\% 20Minutes \% 2025\% 2010 $\% 2007 \% 20 \mathrm{BIC} \% 20$ Pavilion.pdf

Karina managing conference bureau. (2003). Daily Echo. Retrieved February 1, 2009, from http://archive.bourne mouthecho.co.uk/2003/3/18/82136.html

Lawson, F. (2000). Congress, conventions and exhibition facilities. Oxford, UK: Architectural Press.

Leask, A., \& Hood, G. (2000). Unusual venues as conference facilities. In W. Roehl (Ed.), Proceedings of the 
Conference/Expo Summit VIII. Las Vegas: University of Nevada.

Lundtorp, S. (2002). A working paper: Testing a model for tourism development. The case of the Island of Bornholm. Research Centre of Bornholm, Denmark.

Macdonald. (2007). Refurbished Hotel New Blossoms in the Heart of Chester. Retrieved January 5, 2007, from http://www.macdonaldhotels.co.uk/press/press_170407 _Blossoms_Refurbished.htm

Meetings Industry Association. (2000). UK 1999 Conference Market Survey. Northampton, UK: Author.

Oppermann, M. (1996). Convention cities-images and changing fortunes. The Journal of Tourism Studies, 7(1), 10-19.

Paine, A. (1993, May). The university conference market. Insight.

Pemble, A. (2002, September). Academic venues: Educated choice. In Conference and Incentive Travel (pp. 51-54). Haymarket Publication.

Plog, S. G. (1972). Why destination areas rise and fall in popularity. Cornell Hotel, Restaurant \& Administration Quarterly, 14(3), 13-16.

Priestley, G., \& Mundet, L. (1998). The post stagnation phase of the resort lifecycle. Annals of Tourism Research, 25, 85-111.

Richards, G., \& Richards, B. (1994). Developing corporate business for hotel through conferences and exhibitions. Journal of Vacation Marketing, 1(1), 61-69.

Robinson, L. S., \& Callan, R. J. (2001). The UK conference and meetings industry: Development of an inventory for attributional analysis. Journal of Convention \& Exhibition Management, 2(4), 65-79.

Russell, R., \& Faulkner, B. (2004). Entrepreneurship, chaos and tourism area lifecycle. Annals of Tourism Research, $31,556-579$.
Rutherford, D. G. (1990). Introduction to the conventions expositions and meetings industry. New York: Van Nostrand Reinhold.

Saunders, D. (2001, November/December). Unusual venues, remarkable locations. In Conference and Incentive Travel (pp. 37-42). Haymarket Publication.

Shallcross, W. (1998, January). The British conference market. Insights.

Shone, A. (1998). The business of conferences. Oxford: Butterworth Heinemann.

Spiller, J. E., \& Ladkin, A. (2001). The MICE industry in London: A research opportunity. In Cauthe National Research Conference, February 7-10. Canberra, Australia.

Stansfield, C. (1978). Atlantic City and the resort cycle. Annuals of Tourism Research, 5, 238.

Travel Industry Monitor. (1991, March). Hotels dominate the UK conference market. Business International Limited, 12.

Twickenham Experience. (2008). New South Stand. Retrieved February 15, 2009, from http://www.twickenham experience.com/about-us/new-south-stand

Vernon, M. (1966). Business: The key concepts. London: Routledge.

Weaver, D., \& Opperman, M. (2002). Tourism management. Brisbane: John Wiley and Sons.

Whitfield, J. E. (2005). An analysis and critique of an evolving conference industry within the UK from post war to the present day. Ph.D. thesis, Bournemouth University.

Wills, A. (2002, April). Museums and attractions: Stimulating settings. In Conference \& Incentive Travel (pp. 3740). Haymarket Publication. 